\section{RESEARCH SEMINAR IN INTERNATIONAL ECONOMICS}

Department of Economics

The University of Michigan

Ann Arbor, Michigan 48109-1220

SEMINAR DISCUSSION PAPER NO. 50

\title{
Growth and International Investment with Diverging Populations*
}

\author{
by
}

Alan V. Deardorff

The University of Michigan

Revised October 1990

*The original version of this paper was written with financial assistance provided by NSF Grant GS-3073. Support more recently has been provided by the Ford Foundation and the Donner Foundation. I am indebted for their comments especially to Bob Barsky, Jon Eaton, Jim Levinsohn, Matthew Shapiro, T. N. Srinivasan, and Bob Stern, as well as to participants in seminars at the University of Western Ontario, Harvard University, The University of Michigan, and a meeting of the Mid-West International Economics Group at Ohio State University. 



\section{Introduction}

The neoclassical theory of growth, pioneered by Solow (1956) and Swan (1956), has long been regarded as unsatisfactory because of its steady-state implications. In models where growth is driven solely by capital accumulation, and where there are sufficiently diminishing returns to capital per worker, continued long-run growth is impossible in per capita terms. This is thought to be particularly inappropriate in an international context, where experience seems to suggest that countries differ systematically in their abilities to sustain long-run per capita growth. Thus neoclassical growth theory, and especially its application to models of international trade, fell into disfavor after a flurry of activity in the late sixties and early seventies, and was widely regarded as a dead-end theoretical undertaking. ${ }^{1}$

More recently, Romer (1986) and Lucas (1988) have revived the growth theory of a closed economy by incorporating into their models aspects of economies of scale. This turns out to permit countries to sustain per capita growth even in the long run, and indeed it allows the long run growth rate of a country to depend endogenously on its saving behavior. Other authors, most notably Grossman and Helpman in a series of papers, have picked up this theme and applied it in an international context. ${ }^{2}$ In their models, growth rates not only are endogenous, but they can differ across countries and be influenced by policy, including trade policy. This is an exciting development, not only because it revives an undeniably important but previously stagnant area of economic inquiry, but also because it may, at long last, permit economic theory to contribute to the debate on the link between liberal trade and economic development.

In this paper, however, I wish to return briefly to the neoclassical model, in order to suggest that it was not, at least in an international context, quite as deficient as it

${ }^{1}$ See Findlay (1984) and Smith (1984) for surveys of this traditional literature on trade and growth.

${ }^{2}$ See Grossman and Helpman (1989a, 1989b, 1989c). Helpman (1988) has provided an excellent and intuitive introduction to this literature. 
seemed. By allowing for both the international mobility of capital as well as differences across countries in their rates of population growth - what I call diverging populations-I will show that sustained per capita growth is possible after all for some countries, and that the growth rate of such a country does depend on its saving behavior. Thus while the introduction of economies of scale into growth models may well be extremely important in its own right, it is not a necessary condition for achieving these two desirable theoretical outcomes.

In addition, my model displays a property that is familiar in another context from the early growth literature but that has received little attention of late. In the manner of the capitalist class in the two-class Pasinetti (1962) growth model, my country with the slower population growth rate can, if it saves sufficiently, come to dominate the determination of the world return to capital and thus the world growth path. In achieving this result, that country comes to own a significant share of world capital, even though its share of world population becomes negligible. This therefore has important and perhaps disturbing implications for the long run distribution of world income and wealth.

All of this depends crucially, as will become clear, on the assumption that population growth rates differ across countries. This possibility has been neglected in the international growth literature, both old and new, not because it is unlikely to arise in the real world, but because it has been considered theoretically uninteresting. ${ }^{3}$ It is argued that the high-population-growth country, which for convenience I will call South, ${ }^{4}$ will become infinitely large relative to the low-population-growth country, which I will call

${ }^{3}$ The surveys by Findlay (1984) and Smith (1984), for example, make no mention of the possibility that countries may differ in their population growth rates. Khang and Kemp (1973) do construct a two-country model in which population growth rates may differ, and their model in addition allows for two sectors and a variety of savings assumptions. Therefore the model of the present paper is really a special case of theirs. However, Khang and Kemp do not proceed very far with the solution to their model, and in particular they do not derive any of the major results that are derived here.

${ }^{4}$ The labels North and South are used in this paper purely for ease of exposition. The model is not a "North-South" model in the sense, say, of Findlay (1984). 
North, and South will therefore behave ultimately like a closed economy. North, on the other hand, will become so small relative to South as to be unable to affect its terms of trade, and it will therefore behave like the small open economy whose growth has been analyzed extensively in the early literature. ${ }^{5}$ This argument is valid, however, only if international capital flows are excluded from the model. ${ }^{6}$ If capital flows are allowed, then the fact that North's labor force becomes negligible relative to South's does not necessarily imply that it also comes to own a negligible share of world capital.

The reason for this, as well as an indication of the way my model will behave, may be found in the literature on two-class growth models that has grown on the foundation laid by Pasinetti (1962). Pasinetti's model included, in a closed economy, a class of pure capitalists who earned no labor income but instead derived their entire income from capital. Likewise in my model, North's share in world labor income must eventually be zero because of its low population growth rate. North therefore becomes analogous to Pasinetti's capitalist class and may, like the capitalists, continue indefinitely to own a positive share of world capital.

${ }^{5}$ Oniki and Uzawa (1965) handled only the case of identical population growth rates, claiming (p. 16) that "the general case of constant but different rates of population growth is handled without much difficulty." Bardhan $(1966$, p. 39) disputed this claim on the grounds that "growth equilibrium does not exist" unless population growth rates are equal, as he had proved in Bardhan (1965). Since Bardhan defined growth equilibrium as having the property that all variables, including exports and imports, grow at the same rate as population, his claim was quite correct. However, it misses the point that the model does possess a well-defined asymptotic solution in which quantities traded grow at a rate equal to the smaller of the two population growth rates and thus become negligible relative to population in the faster growing country. Kemp $(1969$, p. 226) seems to have been the first to recognize explicitly this tendency for a two-country growth model to resolve itself into the polar cases of small open and large closed economies.

${ }^{6}$ There are no international capital flows in the models cited in the preceding footnote. Kemp (1969, chap. 11) also looked at a model with international investment, but in that model he assumed from the outset that population growth rates were identical. Other treatments of growth and trade in a small open economy, such as Johnson (1971), Vanek (1971), and Deardorff (1974) have also excluded capital flows. Buiter (1981) looked at capital flows in a two-country overlapping-generations model but again assumed that population growth rates were identical. 
This result depends, as Samuelson and Modigliani (1966) pointed out, on a sufficiently large propensity to save by the capitalist class. ${ }^{7}$ Without that, the capitalists' share of total capital becomes negligible, and in a closed economy they may be disregarded. In my model this means that North does become small, in terms of its shares of both labor and capital. It is still worth studying, however, since the growth behavior of a small open economy with mobile capital turns out to be markedly different from that of the small open economy with immobile capital that has previously been studied.

Several conclusions about the behavior of my two-country model may be obtained directly from the two-class literature. The most important of these has come to be called the Pasinetti Paradox, which states that the steady-state return to capital equals the ratio of the population growth rate to the savings propensity of the capitalist class alone. It is therefore independent of the savings behavior of the workers. In my two country model this means that the return to capital depends, in a steady state, on the larger of the two population growth rates and on the savings propensity of North, but it is independent of savings in South.

Samuelson and Modigliani (1966) noted that this result holds only if the capitalists save enough to maintain their ownership of a positive share of total capital. In the dual case of low capitalist savings, they obtain the similar but less remarkable result that the steady-state average product of capital equals the ratio of the population growth rate to the worker's propensity to save. Since this is a property that holds for a closed economy with a single class of savers, it merely verifies, in the model here, that South eventually behaves as though it were closed if savings in North is sufficiently low.

While these conclusions follow immediately from the two-class literature, that literature does not answer all of the questions one might wish to ask about the two country model. How, for example, do growth rates in the two countries separately depend upon

${ }^{7}$ The model will be formulated through most of the paper in terms of constant propensities to save out of income. In section V, however, I will discuss briefly how the model would behave with a form of rational saving instead. 
their savings propensities and population growth rates? What influence does the ability to invest savings internationally have on per capita consumption in the two countries? Such questions have not been considered in the two-class literature because of the omission from the two-class model of any reference to the population of the capitalist class. ${ }^{8}$ Yet the answers to these questions are interesting, as I may indicate by listing the results that I will derive in later sections of this paper:

Proposition 1. The steady-state of the model divides into three cases, according to the relative size of the savings propensity in North. In Case I, with a low savings propensity, North grows only as fast as its own population growth rate and thus remains small relative to South. In Case II, with a somewhat higher savings propensity, North grows more rapidly than its own population forever, but nonetheless continues to own only a negligible share of world capital. In Case III, with an even higher savings propensity, North grows as rapidly as population in South, and North also owns a significant share of world capital.

Proposition 2. North can, by changing its savings propensity, affect its own steady-state growth rate within the limits imposed by the two population growth rates.

Proposition 3. Steady-state per capita consumption in South is unaffected by the savings propensity of North in Cases I and II, and increases with that savings propensity in Case III.

Proposition 4. Per capita consumption in North approaches a constant steady-state level only in Case I. In Cases II and III, per capita consumption in North grows exponentially forever, with a rate of exponential growth that increases with its

${ }^{8}$ This omission is understandable, considering the original purposes of such models, since factor returns and shares do not depend, in steady state, on the size or rate of growth of the capitalist population. 
savings propensity in Case II and remains constant (equal to the difference between the two population growth rates) in Case III.

These propositions are in striking contrast to the results of early neoclassical growth models, both of closed and of open economies, and they are much more reminiscent of the recent literature on growth with economies of scale. Throughout the neoclassical literature, it has been accepted that a country cannot sustain growth of its income at a rate greater than its population growth rate, unless there is some form of technical progress. It follows that it cannot affect that rate of growth through its savings behavior, unless the rate of technical progress in turn depends in some way on its rate of savings. Now it appears, in propositions 1 and 2 above, that a country, even with a stationary constant-returns-to-scale technology, can use investment in a more rapidly growing economy to sustain growth more rapid than its own population growth rate, and also that it can influence its growth rate through its savings propensity. The Solow phenomenon still operates, of course, but it is now the foreign population growth rate that limits a country's rate of growth. It is clear from Proposition 4 that this has important implications for the welfare of the country that has this opportunity. Furthermore, the benefits in terms of per capita consumption that North obtains by investing abroad are not obtained at the expense of South, as is clear in Proposition 3.

In subsequent sections of this paper I will present the model more formally and prove the foregoing propositions. I will also indicate the dividing lines that separate the three cases. The model I use for this purpose is a simplified version of Kemp's (1969, Chap. 11) model of trade, investment, and growth. I simplify his model considerably, however, by abstracting from trade and assuming that there is only one good, which is produced everywhere in the world. This simplification makes the extension of the model to countries with different population growth rates more manageable.

In Section II I begin by analyzing growth of a small economy with mobile capital. A small economy is one whose shares of both world labor and world capital are negligible, 
so that it faces a rate of return to capital that is given from outside. It therefore may correspond to either of Cases I and II mentioned earlier. In Section III I present the more general two-country model and derive its asymptotic properties. Sections II and III, then, will complete the proofs of Propositions 1 and 2. In Section IV I turn to the behavior of consumption in the two countries, proving Propositions 3 and 4. Finally, in Section V, I discuss the possibility of extending the model by introducing trade, by assuming capital to be less-than-perfectly mobile, by adding additional countries, by altering the savings assumption, and by allowing for nontraded goods.

This model is primarily intended as a description of the growth of countries with internationally mobile capital. It is, however, formally identical to a two-class model of a single economy, and it has straightforward implications for the origin and behavior of the classes in such a model. I discuss these implications in section VI.

\section{The Small Country Case}

Consider first the growth of a small country that has access to a large international capital market. By abstracting from trade, this model becomes a modification of Solow's (1956) growth model of a closed one-sector economy. The modification, of course, is to include as income its earnings on capital invested abroad.

I make the familiar neoclassical assumptions that gross investment equals savings, that savings is a constant fraction, $\mathrm{s}$, of income, and that the labor force grows exponentially at a constant rate $\mathrm{n}$. With these assumptions the country's dynamic behavior is described by the following pair of differential equations:
(1) $\mathrm{dL} / \mathrm{dt}=\mathrm{nL}$
(2) $\mathrm{dK} / \mathrm{dt}=\mathrm{s}[\mathrm{wL}+\mathrm{rK}]$, 
where $\mathrm{K}$ and L are the country's labor force and capital stock respectively. ${ }^{9}$

The bracketed expression in (2) is the country's income. Note that (2) does not distinguish between capital invested domestically and capital invested abroad. This will be appropriate if there are perfect domestic factor markets. This assumption, together with a linearly homogeneous production function for domestic output, also allows $\mathrm{w}$ to be uniquely determined by $\mathrm{r}$. Thus both $\mathrm{w}$ and $\mathrm{r}$ are parameters given by the rest of the world.

The system $(1,2)$ reduces to a single differential equation in the capital-labor ratio, $\mathrm{k}=\mathrm{K} / \mathrm{L}$.

$$
\mathrm{dk} / \mathrm{dt}=\mathrm{s}[\mathrm{w}+\mathrm{rk}]-\mathrm{nk}
$$

The behavior of this differential equation is easily seen in Figure 1, which is largely familiar from expositions of the Solow closed economy growth model. $f(k)$ is the production function in intensive form. Given $r$, enough capital per head will be employed at home, $\mathrm{k}^{\mathrm{e}}$, to equate $f^{\prime}\left(k^{e}\right)=r$, and the economy's per capita income, $y$ - including income from capital invested abroad - is the straight line tangent to $f(k)$ with slope r. Per capita savings, which is the first term on the right-hand-side of (3), is the fraction of this line, sy, and need only be compared to a ray from the origin, $\mathrm{nk}$, to determine where $\mathrm{k}$ is rising, falling, or stationary over time.

For the value of $\mathrm{n}$ shown, this means that $\mathrm{k}$ is driven over time toward the steady state level, $\mathrm{k}^{*}$. The only difference from the Solow model in this case is a slightly higher steady-state capital-labor ratio (compare the intersection of $\mathrm{nk}$ with the curve $\mathrm{sf}(\mathrm{k})$, which would be per capita savings in a closed economy) and the fact that the country invests $\mathrm{k}^{*}-\mathrm{k}^{\mathrm{e}}$ of its capital abroad. ${ }^{10}$ In this case, the model retains the important

${ }^{9}$ Capital does not depreciate here, though a constant rate of depreciation could be incorporated without substantively altering the results.

${ }^{10}$ Of course, for higher $\mathrm{n}$ or lower $\mathrm{s}$, steady state would be to the left of $\mathrm{k}^{\mathrm{e}}$ and the country would import capital. 
characteristics of Solow's closed-economy growth model. The growth rates of capital and income both ultimately converge to the population growth rate, $\mathrm{n}$, and there is no sustained growth of the economy in per capita terms. This corresponds to Case I mentioned in Proposition 1 of the introduction.

For other parameters, however, the result can be quite different. Consider the lower population growth rate, $n^{\prime}$. In this case, n'k does not intersect sy and the economy accumulates capital without bound. There is no steady state, in the usual sense of a constant capital-labor ratio. But the model does possess well-defined asymptotic properties. To see this, solve equation (3) explicitly as follows:

$$
k(t)=\left(k^{0}-k^{*}\right) \exp [(s r-n) t]+k^{*}
$$

where $\mathrm{k}^{0}$ is the initial capital-labor ratio, and

$$
\mathrm{k}^{*}=\frac{-\mathrm{sw}}{\mathrm{sr}-\mathrm{n}} \text {. }
$$

The behavior of this solution clearly depends on the expression $(s r-n)$. If $s<n / r$, then the exponential term in (4) disappears over time, and the economy converges to $\mathrm{k}^{*}$. This is Case I as just described.

The rate $n^{\prime}$ in Figure 1, on the other hand, corresponds to the more interesting case where $r$ and $s$ are large enough to make $(s r-n)>0$. In that case $k$ must grow indefinitely, and it is the constant term in (4), $\mathrm{k}^{*}$, that becomes insignificant. The term $(\mathrm{sr}-\mathrm{n})$ is now the asymptotic rate of growth of the capital-labor ratio. It follows that $\mathrm{sr}$ is the asymptotic rate of growth of both capital and income - the latter since the wage component of income becomes insignificant.

It is here then - in what I called Case II in the introduction - that this growth model exhibits behavior that is radically different from traditional neoclassical models. Not only is it possible for a country to grow indefinitely at a rate greater than its 
population growth rate, but it can also increase this rate of growth by increasing its savings propensity. The reason for this, of course, is that the country is freed, by the international capital market, from the constraint of diminishing returns. In a completely closed economy with constant returns to scale, the productivity of capital is limited by its own labor force, and diminishing returns prevent the economy from increasing its capitallabor ratio indefinitely. In this small country model, on the other hand, the return to capital that it can earn by investing abroad is constant.

It remains to be seen, however, whether the small-country assumption of this model can possibly be valid. In the asymptotic solution the small country invests an ever increasing fraction of its ever increasing capital stock abroad. Is it possible for the rest of the world to absorb this much capital without it affecting the rate of return? If population abroad grows no more rapidly than at home, then the answer must certainly be no. For then the small country's capital stock would be growing faster than world population, and diminishing returns would have to set in just as in a closed economy.

But if the population growth rate is higher abroad than at home, then the smaller country can increase its capital stock faster than its own population and rely on the more rapid population growth in the rest of the world to keep the return to capital from falling. This possibility is explored further in the next section.

\section{The Two-Country Case}

In the two-country model the behavioral assumptions for each country are the same as those used for the small country in Section II. The return to capital and the wage rate, however, are determined by factor productivities in the two countries, together with the condition that the return to capital be the same in both.

Let the two countries have identical linearly homogeneous production functions, so that the average product of labor in both is a function, $f$, only of the capital-labor ratio employed. With competitive factor pricing and perfect capital mobility, it follows that the ratios of capital to labor employed in each country will equal the world capital-labor ratio. 
The competitive return to capital then depends only on the world capital-labor ratio, $\mathrm{K} / \mathrm{L},{ }^{11}$

(6) $\quad \mathrm{r}=\mathrm{f}^{\prime}(\mathrm{K} / \mathrm{L})$,

as does the competitive wage

(7) $\quad w=f(K / L)-r K / L$.

The dynamic equations of the two-country case consist of equations (1) and (2) of Section II, repeated for each country:

$$
\mathrm{dL}_{\mathrm{i}} / \mathrm{dt}=\mathrm{n}_{\mathrm{i}} \mathrm{L}_{\mathrm{i}}
$$$$
\mathrm{i}=1,2
$$

$$
\mathrm{dK}_{\mathrm{i}} / \mathrm{dt}=\mathrm{s}_{\mathrm{i}}\left[\mathrm{wL}_{\mathrm{i}}+\mathrm{rK}_{\mathrm{i}}\right]
$$$$
\mathrm{i}=1,2 \text {. }
$$

$\mathrm{K}_{\mathrm{i}}$, of course, is the capital owned by country $\mathrm{i}$, not the capital installed in that country. Notice that there may be different population growth rates, $n_{i}$, as well as different savings propensities, $s_{i}$, in the two countries. In particular, I assume without loss of generality that

$$
\mathrm{n}_{1}>\mathrm{n}_{2}
$$

so that country 1 is South of the introduction.

Equations (8) and (9), with substitution from (6) and (7), form a system of four differential equations in the four unknowns, $\mathrm{K}_{\mathrm{i}}, \mathrm{L}_{\mathbf{i}}, \mathrm{i}=1,2$. The system is more readily analyzed, however, by introducing the following new variables.

Let

${ }^{11}$ Variables without subscripts now pertain to the world, while country variables will now carry country numbers as subscripts. 


$$
\lambda=\mathrm{L}_{2} /\left(\mathrm{L}_{1}+\mathrm{L}_{2}\right)
$$

be country 2's share of the world labor force; let

$$
\rho=\mathrm{K}_{2} /\left(\mathrm{L}_{1}+\mathrm{L}_{2}\right)
$$

be the ratio of country 2's capital to the world labor force; and let

$$
\mathrm{k}=\mathrm{K} / \mathrm{L}=\left(\mathrm{K}_{1}+\mathrm{K}_{2}\right) /\left(\mathrm{L}_{1}+\mathrm{L}_{2}\right)
$$

be the world capital-labor ratio.

The with some manipulation, the system (8-9) becomes

$$
\begin{aligned}
& \mathrm{d} \lambda / \mathrm{dt}=\lambda(1-\lambda)\left(\mathrm{n}_{2}-\mathrm{n}_{1}\right) \\
& \mathrm{d} \rho / \mathrm{dt}=\left(\mathrm{s}_{2} \mathrm{r}-\mathrm{n}_{1}\right) \rho+\left[\mathrm{s}_{2} \mathrm{w}+\left(\mathrm{n}_{1}-\mathrm{n}_{2}\right) \rho\right] \lambda \\
& \mathrm{dk} / \mathrm{dt}=\mathrm{s}_{1}(\mathrm{w}+\mathrm{rk})-\mathrm{n}_{1} \mathrm{k}+\left(\mathrm{s}_{2}-\mathrm{s}_{1}\right) \mathrm{r} \rho+\left[\left(\mathrm{s}_{2}-\mathrm{s}_{1}\right) \mathrm{w}+\left(\mathrm{n}_{1}-\mathrm{n}_{2}\right) \mathrm{k}\right] \lambda
\end{aligned}
$$

Since $r$ and $\mathrm{w}$ are functions only of $\mathrm{k}$ in (6) and (7), the equations (14), (15), and (16) form a closed system of three differential equations in the three unknowns, $\lambda, \rho$, and $\mathrm{k}$.

To see the asymptotic properties of this system, observe first that $\lambda$ must go to zero over time in (14), since $n_{2}$ has been assumed less than $n_{1}$. Thus, the asymptotic equations of motion for $\rho$ and $\mathrm{k}$ can be simplified considerably by letting $\lambda=0$ in (15) and (16):

$$
\mathrm{d} \rho / \mathrm{dt}=\left(\mathrm{s}_{2}{ }^{\mathrm{r}-\mathrm{n}_{1}}\right) \rho
$$

$$
\mathrm{dk} / \mathrm{dt}=\left[\mathrm{s}_{1} \mathrm{f}(\mathrm{k})-\mathrm{n}_{1} \mathrm{k}\right]+\left(\mathrm{s}_{2}-\mathrm{s}_{1}\right) \mathrm{r} \rho
$$


This system of two differential equations can be analyzed in terms of the phase diagram that is derived as the lower quadrant of Figure 2.

First, $\mathrm{d} \rho / \mathrm{dt}=0$ in (17) requires either that $\rho=0$ or that $\mathrm{s}_{2} \mathrm{r}=\mathrm{n}_{1}$. Since $\mathrm{r}$ depends only on $k$, the latter fixes a vertical line at a value $k^{*}$ such that $s_{2} f^{\prime}\left(k^{*}\right)=n_{1}$. This in turn is identifiable in the upper quadrant by the curve $s_{2} f(k)$ being parallel to the ray $n_{1} k$.

Solution to $\mathrm{dk} / \mathrm{dt}=0$ in (18) is more complex, since it involves both $\mathrm{k}$ and $\rho$. However, it is easy to anchor the solution along the $\mathrm{k}$-axis, where $\rho=0$ and what remains of (18) is the growth equation of the closed-economy Solow growth model. Thus $\mathrm{dk} / \mathrm{dt}=0$ along the $k$-axis at $k^{* *}$, where $s_{1} f(k)$ crosses $n_{1} k$ in the upper quadrant:

$$
\mathrm{s}_{1} \mathrm{f}\left(\mathrm{k}^{* *}\right)=\mathrm{n}_{1} \mathrm{k}^{* *}
$$

For $\mathrm{k}$ larger than $\mathrm{k}^{* *},(18)$ can be solved with $\mathrm{dk} / \mathrm{dt}=0$ to yield

$$
\rho=\frac{n_{1} k-s_{1} f(k)}{\left(s_{2}-s_{1}\right) f^{\prime}(k)}
$$

which rises with $\mathrm{k}$ as long as $\mathrm{s}_{2}>\mathrm{s}_{1}$, which I assume. Thus the $\mathrm{dk} / \mathrm{dt}=0$ locus in the lower quadrant of Figure 2 slopes down and to the right, starting at $\mathrm{k}^{* *}$, and, if $\mathrm{k}^{* *}<\mathrm{k}^{*}$, crosses $\mathrm{d} \rho / \mathrm{dt}=0$ at some value $\rho^{*}>0$.

The dynamics of $\rho$ and $\mathrm{k}$ are shown by the arrows, and they lead to convergence - not necessarily monotonic - to the intersection at $\left(\mathrm{k}^{*}, \rho^{*}\right) .{ }^{12}$ This is the Case III solution described in the introduction. North now comes to own a permanently nonnegligible share of world capital, even though North's share of world labor, $\lambda$, goes to zero. Since $\rho=\mathrm{K}_{2} /\left(\mathrm{L}_{1}+\mathrm{L}_{2}\right)$ becomes a positive constant, $\mathrm{K}_{2}$ must grow asymptotically at the same rate as world population, $\mathrm{n}_{1}$.

\footnotetext{
${ }^{12}$ The stability of this dynamic process will be discussed further below.
} 
An important property of this Case III solution is that, while $\rho$ depends on $\mathrm{s}_{1}, \mathrm{k}^{*}$ does not. Thus $r$ and $w$, which depend only on $k$, are also independent of $s_{1}$ in the Case III steady state. This is clear directly from (18), where $d \rho / d t=0$ is consistent with a positive solution for $\rho$ only if $\mathrm{r}=\mathrm{n}_{1} / \mathrm{s}_{2}$. And this is the familiar result mentioned earlier from twoclass growth models, and known as the Pasinetti Paradox. Indeed this model is formally identical to the two-class model, since North's low population growth rate drives its share of labor income to zero, and thus it acts as if it earned only profits.

The Case III solution shown in Figure 2 for the growth rate $\mathrm{n}_{1}$ arises only because $\mathrm{k}^{* *}<\mathrm{k}^{*}$, so that the two curves do intersect at strictly positive $\rho$. If they do not - as shown by the larger $\mathrm{k}^{* * 1}$ implied by a higher $\mathrm{s}_{1}^{\prime}$ - then the dynamics of the model take it to $\mathrm{k}^{* *}$ itself, and $\mathrm{k}^{*}$ becomes irrelevant. ${ }^{13}$ In that case the world capital stock is determined entirely in country 1 as though it were a closed economy, and country 2 can be in either of the small-country cases, I or II, discussed in Section II.

It is now possible to delineate the bounds on parameters that will give rise to each of the three cases. Let $\mathrm{r}^{* *}=\mathrm{f}^{\prime}\left(\mathrm{k}^{* *}\right)$ be the rental rate that would arise in country 1 as a closed economy, and that will arise in Cases I and II if they occur. In section II it was already observed that Case I requires $\mathrm{s}_{2} \mathrm{r}^{* *}<\mathrm{n}_{2}$, while Case II requires the opposite. Now, since $\mathrm{k}^{*}$ is defined by $\mathrm{f}^{\prime}\left(\mathrm{k}^{*}\right)=\mathrm{n}_{1} / \mathrm{s}_{2}$, it follows that ${ }^{14}$

$$
\mathrm{k}^{*}>\mathrm{k}^{* *} \text { as } \mathrm{n}_{1} / \mathrm{s}_{2}<\mathrm{r}^{* *}
$$

Thus the three cases arise as follows:

$$
\text { Case I: } \quad \mathrm{s}_{2}<\mathrm{n}_{2} / \mathrm{r}^{* *}
$$

${ }^{13}$ Recall that the entire $\mathrm{k}$-axis is also consistent with $\mathrm{d} \rho / \mathrm{dt}=0$. In Case III the point $\left(\mathrm{k}^{* *}, 0\right)$ was also a steady-state solution, but it was dynamically unstable.

${ }^{14}$ Since $\mathrm{k}^{* *}=\mathrm{f}^{-1}\left(\mathrm{r}^{* *}\right)$ while $\mathrm{k}^{*}=\mathrm{f}^{-1}\left(\mathrm{n}_{1} / \mathrm{s}_{2}\right)$, and $\mathrm{f}^{\prime}$ is monotonically decreasing. 
Case II: $\quad \mathrm{n}_{2} / \mathrm{r}^{* *}<\mathrm{s}_{2}<\mathrm{n}_{1} / \mathrm{r}^{* *}$

Case III: $s_{2}>n_{1} / r^{* *}$

With $\mathrm{n}_{1}>\mathrm{n}_{2}$, all that is required for all these cases to be consistent with fractional values of $s_{2}$ is that $n_{1} / r^{* *}<1$. Thus each of the three cases can arise, depending on the values of the various savings and population growth parameters, as long as $r^{* *}>n_{1} \cdot{ }^{15}$

Since $\mathrm{r}^{* *}$ is the steady-state return to capital for country 1 as a closed economy, this condition, $\mathrm{r}^{* *}>\mathrm{n}_{1}$, bears obvious resemblance to the "golden rule" of savings. It is well known that, in order to maximize its steady-state per capita consumption, a closed economy must save enough to set its steady-state return to capital equal to its rate of population growth. That is, golden rule savings by country 1 will yield $\mathrm{r}^{* *}=\mathrm{n}_{1}$. If country 1 fails to follow the golden rule, presumably by saving less than the rule indicates, then it will indeed be true that $r^{* *}>n_{1}$, and Case III will be possible for values of $s_{2}$ less than unity.

\section{Consumption}

The analysis so far shows that a country can benefit considerably, in terms of its rate of growth of income, by investing in a second country with a more rapidly growing population. The role of the foreign population is that its rapid growth keeps the return to capital from falling. It is natural to wonder, in view of this result, about the effects that this international investment may have on the welfare of the two countries, and particularly on the welfare of the host country, South. While a general intertemporal examination of welfare in this model would be beyond the scope of this paper, it is fairly

${ }^{15}$ The importance of each case also depends on the solution being dynamically stable. Samuelson and Modigliani (1966) have proved both local stability of the Pasinetti equilibrium (my Case III) and global stability of their "dual" equilibrium (my Cases I and II). In addition, Guha (1972) has proved global stability of the Pasinetti equilibrium if the elasticity of factor substitution is greater than $1 / 2$. 
easy to generate conclusions about the asymptotic behavior of per capita consumption in the two countries.

These problems have simple solutions in Cases I and II. In these cases, country 2's share of world capital, $\rho / \mathrm{k}$, is asymptotically zero. Factor prices are then completely determined by the parameters of country 1 and are the same as would prevail if country 1 were closed to foreign investment. It follows that steady-state per capita consumption in country 1 is completely unaffected by country 2 's investment in it.

This is true even though consumption in country 2 itself does depend importantly on its ability to invest abroad. Steady-state per capita consumption in country 2 as long as it remains small (Cases I and II) can be identified simply in Figure 1 as the vertical distance between its per capita income, $\mathrm{y}_{2}$, and the amount of savings it needs for steadystate growth, $\mathrm{n}_{2} \mathrm{k}_{2}$. Evidently, an increase in $\mathrm{s}_{2}$ raises the steady-state capital-labor ratio in Case I and increases per capita consumption as long as the slope of $y_{2}$, which is determined as $\mathrm{r}^{* *}$ in country 1 , is larger than $\mathrm{n}_{2}$. Assuming as just discussed that savings in country 1 is no more than the golden rule, $\mathrm{r}^{* *} \geq \mathrm{n}_{1}$. Together with $\mathrm{n}_{1}>\mathrm{n}_{2}$, this assures that country 2 increases its steady-state per capita consumption in Case I by saving more.

In Case II, country 2's per capita savings grows asymptotically at an exponential rate that equals its rate of accumulation of capital per capita, $\mathrm{s}_{2} \mathrm{r}^{* *}-\mathrm{n}_{2}$. In this case an increase in $\mathrm{s}_{2}$ causes a short-run fall in per capita consumption, as more is saved out of the current income, but this drop is followed by a rise in the exponential rate of growth. Thus increased savings in country 2 has an even greater positive effect on per capita consumption in Case II than in Case I.

The rate of growth of per capita consumption in country 2 can not be increased without bound, however. When $s_{2}$ crosses the dividing line $n_{1} / r^{* *}$, the system passes from Case II into Case III. At that point per capita consumption in country 2 is growing at the rate $\left(n_{1}-n_{2}\right)$. Once $s_{2}$ is greater than $n_{1} / r^{* *}$, country 2's capital stock grows at the 
rate $n_{1}$ regardless of $s_{2}$. Thus, its capital-labor ratio and its per capita consumption both grow at the rate $\left(n_{1}-n_{2}\right)$, and this growth rate is unaffected by further increases in $s_{2}$.

In Case III, though, country 2 owns a positive fraction of the world's capital stock, virtually all of which is located in country 1 . One might therefore expect per capita consumption in the host country 1 to be adversely affected by increases in $s_{2}$, since such increases cause country 2 to own a larger share of world capital. This is not true, however, as can easily be verified.

In Case III, country 1's capital-labor ratio approaches a constant value, $\mathrm{k}^{*}-\rho^{*}$. Thus it behaves like a country in Case I that is an importer of capital rather than an exporter. The constancy of its capital-labor ratio implies, from an equation analogous to (3), that

$$
\mathrm{s}_{1} \mathrm{y}_{1}=\mathrm{n}_{1} \mathrm{k}_{1}
$$

Solving for $y_{1}$, per capita consumption in country 1 is

$$
c_{1}=\left(1-s_{1}\right) y_{1}=\left(1-s_{1}\right) n_{1} k_{1} / s_{1}
$$

which therefore depends positively on $k_{1}$. But it is easily seen from Figure 1 that a Case $I$ country that imports capital in steady state must increase its own capital-labor ratio when $r$ falls. Since a rise in $s_{2}$ in Case III causes $k^{*}$ to rise and therefore $r *$ to fall in Figure 2, it follows that steady-state $c_{1}$ rises with $s_{2}$. Thus, while it is true that country 2 benefits from investing in the foreign country with abundant labor, it is not true that it benefits at the expense of that country.

It should be stressed that these conclusions about per capita consumption, verifying Propositions 3 and 4 of Section I, do not constitute a complete treatment of the welfare implications of international investment. I have looked here only at steady-state per capita consumption, and I have therefore completely ignored any effects on per capita 
consumption during the approach to steady state. Furthermore, by looking only at per capita consumption, one misses entirely those side effects of direct investment that are often cited in arguments for and against it but that either are noneconomic or do not fit conveniently into the model. ${ }^{16}$ Note, however, that this model does suggest that these side effects may not be too important if they depend upon substantial foreign ownership of a country's installed capital stock. Country 2 does not need to own a substantial portion of Country 1's installed capital in order to benefit from direct investment. On the contrary, increased savings by country 2 can increase its rate of growth only so long as it does not own a positive fraction of world capital.

\section{Extensions of the Model}

The purpose of this paper has been to examine several implications of two assumptions: that populations grow at different rates in different countries, and that capital is mobile between countries. To do this I have used a very simple growth model that is intended to bring out the significance of these assumptions most clearly. This exercise would be of little value, however, if the results actually depended on the simplicity of the model, rather than on the assumptions about capital mobility and population growth. In this section, therefore, I discuss briefly several of these simplifying assumptions and the likelihood that they contribute to the results.

\section{Trade}

One noticeable drawback of the model is that it does not explicitly include trade in goods. The single good produced in both countries does flow between them - as it must to keep payments balanced in the presence of capital flows and income on international investment - but since there is only one good there can be no commodity trade in the usual sense. It seems unlikely, however, that the inclusion of trade in the model would

${ }^{16}$ These side effects include loss of political or cultural autonomy by the country receiving capital, possible employment effects in the two countries, and the role of international investment as a means of transmitting technology. 
significantly alter the results. The inclusion of trade would be most easily accomplished by having two sectors, one producing consumption goods and the other producing investment goods. The model would then be formally identical to Stiglitz's (1967) two-sector two-class growth model. Stiglitz found much the same kinds of growth behavior that Samuelson and Modigliani (1966) had found in the one-sector model, except that he found local instability possible for the Pasinetti-type equilibrium (analogous to Case III).

Of course, Stiglitz did not examine trade in goods between his classes (countries). But Kemp's (1969) analysis of growth with trade and capital mobility suggests that not much would have been learned had he done so, since the location of capital, and therefore the pattern of trade, are indeterminate in such a model.

Finally, the model here of the small country case, as presented in Section II, did not actually use the one-sector assumption. Equations (1-5) continue to be valid with any number of sectors so long as the country remains too small to influence the given factor prices. Since the small country exhibited, in Case II, the most striking results (i.e., a growth rate larger than $n$ and subject to change through $\mathbf{s}$ ) it seems unlikely that the other propositions would fail either with the inclusion of trade.

\section{More than Two Countries}

A second drawback of the model is that it includes only two countries. This is easily rectified. The equations of the model are the same as equations (6)-(9), except that equations (8) and (9) now extend over $\mathrm{i}=1, \ldots, \mathrm{m}$, where $\mathrm{m}$ is the number of countries.

Also, of course, $K$ and $L$ are now defined as the sums of the respective $K_{i}$ and $L_{i}$ over all m countries as well.

Assume that the countries are numbered in decreasing order of their population growth rates,

$$
\mathrm{n}_{1}>\mathrm{n}_{2} \geq \mathrm{n}_{3} \geq \ldots \geq \mathrm{n}_{\mathrm{m}}
$$


where country 1 is assumed to have a strictly higher population growth rate than any other country. ${ }^{17}$ As before, it is convenient to transform the variables of the model to world per capita terms, $\lambda_{i}=L_{i} / L$ and $\rho_{i}=K_{i} / L$. The time path of $\lambda_{i}$ can then be expressed, from (8), as

$$
\frac{d \lambda_{i}}{d t}=\left(n_{i}-\bar{n}\right) \lambda_{i}
$$

where

$$
\bar{n}=\sum_{j=1}^{m} \lambda_{j} n_{j}=\frac{1}{L} \frac{d L}{d t}
$$

is the rate of growth of world population and varies over time. While it is no longer the case that all of these $\lambda_{i}$ 's must evolve monotonically, it is still true that all of them except $\lambda_{1}$ must move asymptotically toward zero. ${ }^{18}$ Thus

$$
\lim _{t \rightarrow \infty} \lambda_{1}=1
$$

and

$$
\lim _{t \rightarrow \infty} \bar{n}=n_{1}
$$

Differentiating $\rho_{\mathrm{i}}$ and using (9)

${ }^{17}$ If two or more countries tie for having the highest population growth rate, then they can be aggregated into a single country. If they have different savings rates among them, however, the aggregate will behave like a two-class economy and the analysis will be somewhat more complicated than appears here.

${ }^{18}$ This follows since all $\lambda_{i}$ for which $n_{i}<\bar{n}$ do converge to zero. In doing so, their weights in $\bar{n}$ fall to zero, eventually forcing the $\lambda_{i}$ for all other $i>1$ to also have $n_{i}<\bar{n}$. 


$$
\frac{\mathrm{d} \rho_{\mathrm{i}}}{\mathrm{dt}}=\mathrm{s}_{\mathrm{i}} \mathrm{r} \rho_{\mathrm{i}}+\mathrm{s}_{\mathrm{i}} \mathrm{w} \lambda_{\mathrm{i}}-\rho_{\mathrm{i}} \overline{\mathrm{n}}
$$

Also

$$
\frac{d k}{d t}=\sum_{i=1}^{m} \frac{d \rho_{i}}{d t}
$$

Using (30) and (31), these become

$$
\begin{aligned}
& \lim _{t \rightarrow \infty} \frac{d k}{d t}=\left[s_{1} f(k)-n_{1} k\right]+f^{\prime}(k) \sum_{i=2}^{m}\left(s_{i}-s_{1}\right) \rho_{i} \\
& \lim _{t \rightarrow \infty} \frac{d \rho_{i}}{d t}=\left[s_{i} f^{\prime}(k)-n_{1}\right] \rho_{i}
\end{aligned}
$$$$
\mathrm{i}=2, \ldots, \mathrm{m}
$$

From (35) one can show that only the country with the highest ${ }^{19}$ savings propensity among countries $2, \ldots, \mathrm{m}$ can maintain a positive share of world capital in the long run. ${ }^{20}$

As a benchmark, let $\mathrm{k}_{\mathrm{i}}^{*}$ be the world capital-labor ratio that would yield a return on capital just sufficient to keep country i's value of $\rho_{\mathrm{i}}$ constant in the long run:

$$
k_{i}^{*}=f^{-1}\left(\frac{n_{1}}{s_{i}}\right)
$$

Then it is easily seen that

${ }^{19}$ Again, if more than one of countries $2, \ldots, \mathrm{m}$ share the same highest savings ratio, then these countries could be aggregated for the purpose of the long-run analysis. For simplicity though I will assume that such ties do not occur. appendix.

${ }^{20}$ What follows is only a sketch of a proof. A more formal proof is in the 


$$
\lim _{t \rightarrow \infty} k \geq k_{i}^{*}
$$

$\mathrm{i}=2, \ldots, \mathrm{m}$

since otherwise $\rho_{\mathrm{i}}$ for any $\mathrm{i}$ that violates (37) would eventually, from (35), grow to exceed

k. Noting that $\mathrm{k}_{\mathrm{i}}^{*}$ is positively related to $\mathrm{s}_{\mathrm{i}}$, it follows that the world capital-labor ratio converges to a value that is at least as high (and hence $r$ to a value that is at least as low) as would be needed to sustain a constant value of $\rho_{\mathrm{i}}$ in the highest saving country among $2, \ldots, \mathrm{m}$ - call it country $\hat{\mathrm{i}}$. Therefore all others of these countries must asymptotically find $\mathrm{s}_{\mathrm{i}} \mathrm{f}^{\prime}(\mathrm{k})<\mathrm{n}_{1}$ in (35) and their $\rho_{\mathrm{i}}$ go to zero:

$$
\lim _{t \rightarrow \infty} \rho_{\mathrm{i}}=0 \quad \text { for } \mathrm{i} \neq 1, \hat{\mathrm{i}}
$$

where

$$
\mathrm{s}_{\mathrm{i}} \geq \mathrm{s}_{\mathrm{i}} \quad \text { for } \mathrm{i}=2, \ldots, \mathrm{m}
$$

Thus in the long run, the m-country model reduces to the 2-country case. Only country 1 owns an asymptotically positive share of world labor, and only country 1 together with the highest saving of the other countries, country $\hat{\imath}$, own asymptotically positive shares of world capital. All other countries disappear, in terms of their importance to the world system. Of course each of them continues to be of interest to its own residents, and their behavior can still be described by the analysis in section II of the small-country case.

\section{Imperfect Capital Mobility}

A third possible drawback of the model is that a desirable assumption - that capital is mobile - takes the extreme form that capital is perfectly mobile. Perfect mobility of capital is certainly not realistic, but it is probably a reasonable approximation to reality for the long-run problems of this paper. For if capital is mobile at all, then it 
should move in response to inter-country differentials in its rate of return. In the long run, such capital movements, even if they occur only slowly, should bring about some fixed relationship between returns to capital in different countries. Such a fixed relationship is really all that is needed for the qualitative results of this paper. ${ }^{21}$

\section{Alternative Savings Behavior}

A fourth drawback of the model is the simplicity of the savings assumption. A constant savings propensity, though it is a staple of the early growth literature, is not easily justified by any sort of optimization. ${ }^{22}$ The advantage of the constant savings propensity therefore is primarily expositional, and the fact that it permits discussion of what alternative levels of savings may imply, as opposed to what levels of savings are most likely to occur.

Still it is reasonable to ask whether the behavior described here could still arise if savings were a matter of choice. One step in this direction would be to let the savings rate be a function of the interest rate, $r$, and perhaps also of the wage and the per capita capital stock. Since all of these variables depend on the capital-labor ratio, the effect of such assumptions would be to alter the shapes of the curves labelled sf in Figures 1 and 2. Certain problems of nonuniqueness could arise if a savings rate were to rise or to fluctuate with increases in a capital-labor ratio. But otherwise the analysis should not be much affected. For example, if country 2 saves enough more than country 1 for any particular value of the interest rate, then cases like II and III will still be possible.

${ }^{21}$ In Deardorff (1987) I have examined a numerical simulation model based upon the structure of the model presented here, but with imperfectly mobile capital. While for the particular parameters used there only the Case I solution arises, experimentation with the model outside of the paper confirmed that the other cases could arise as well and that the model with imperfect capital mobility behaved essentially the same as the model here.

${ }^{22}$ Kurz (1968) was able to construct an intertemporal utility function for which a constant savings propensity would be optimal in the Solow growth model, but it is not clear that the same could be done here, especially if the same savings propensities are to . continue to be optimal for alternative values of other parameters. 
To go further toward a complete optimizing model of saving is also possible, though tractable models tend to lead to conclusions in this context that I regard as somewhat extreme. For example, suppose that savers in both countries attempt to maximize the following simple intertemporal utility function:

$$
\mathrm{U}_{\mathrm{i}}=\int_{0}^{\infty} \mathrm{e}^{-\delta_{\mathrm{i}} \mathrm{t}}\left[\mathrm{c}_{\mathrm{i}}(\mathrm{t})\right]^{\gamma_{\mathrm{i}} / \gamma_{\mathrm{i}} \mathrm{dt}}
$$

where $\delta_{i}$ is the time discount rate of consumers in country $i$ and $\gamma_{i}$ is a parameter such that $\gamma_{\mathrm{i}}<11^{23}$ Maximizing subject to an intertemporal budget constraint with constant (steady-state) values of $r$ and $w$ leads to an optimal consumption path,

$$
c_{i}(t)=c_{0} \exp \left\{\left[\left(r-\delta_{i}-n_{i}\right) /\left(1-\gamma_{i}\right)\right] t\right\}
$$

Incorporating this behavior into the model of this paper, and letting $n_{1}>n_{2}$, it is not difficult to get the Case II steady-state solution. In this case $r$ is set equal to $\delta_{1}+n_{1}$, so that per capita consumption is constant in country 1 and per capita consumption in country 2 therefore grows exponentially at the rate $\left(\delta_{1}-\delta_{2}+n_{1}-n_{2}\right) /\left(1-\gamma_{2}\right)$. If

$$
\delta_{2}<\delta_{1}+\left(\mathrm{n}_{1}-\mathrm{n}_{2}\right)
$$

this rate of growth will be positive, while if

$$
\delta_{2}>\delta_{1}+\gamma_{2}\left(\mathrm{n}_{1}-\mathrm{n}_{2}\right)
$$

it will be less than $n_{1}-n_{2}$, keeping country 2's capital stock a negligible fraction of the world's.

${ }^{23}$ An alternative approach to an intertemporal optimizing model would be to use an overlapping generations model, as in Buiter (1981). In such a model however, unless there are bequests, the capital stock must be acquired anew each period out of labor income and therefore cannot grow indefinitely faster than population. 
Cases I and III also arise with this optimizing behavior, but they take a different

form. In Case I, where (42) holds with the reverse strict inequality, per capita

consumption falls asymptotically over time toward zero in country 2 . Similarly in Case

III, where (43) holds with the reverse strict inequality, if a solution exists, per capita

consumption in country 1 declines toward zero. In this case, $r$ is set as follows to yield a

growth rate of per capita consumption of $n_{1}-n_{2}$ in country 2 ,

$$
r=\delta_{2}+n_{2}+\left(1-\gamma_{2}\right)\left(n_{1}-n_{2}\right)
$$

and country 1 actually ends up acquiring a debt to country 2 which it services using the wages earned by its labor. Also, if $r$ in (44) is lower even than $n_{1}$, then no solution exists, since the present value of 1 's labor income against which it could borrow from country 2 is undefined. Apparently in such a case the discount and population growth rates are so different in the two countries that they each would try to shift their consumption infinitely into the present or the future.

This behavior is sufficiently odd that I do not find it credible, and I have therefore chosen not to make such an optimizing model the basis for my analysis. I suspect that a more sophisticated optimizing model, one with a more general functional relating utility and the time path of consumption, would not have to lead to these difficulties. ${ }^{24}$ Whether such a model would also replicate the qualitative features of my Cases I, II, and III remains to be seen.

\section{Nontraded Goods}

I have not allowed as yet for nontraded goods, which might seem to pose serious problems for the main conclusions of my analysis. After all, if per capita income in a

${ }^{24}$ One possibility, suggested to me by Jon Eaton, would be to make the instantaneous discount rate depend positively on instantaneous utility, in the manner of Uzawa (1968). By also having an upper bound on this discount rate, one can get a Case III solution in which country 2's per capita consumption grows exponentially but country 1 's declines to a constant positive level. 
country grows without bound, then demand for any nontraded goods will presumably also grow, putting increasing pressure on the domestic resources needed to produce them. One might expect therefore that the need to produce nontraded goods would ultimately place even a high-saving country back in the trap of zero per capita growth. By merely sketching how a nontraded good could fit into my analysis, I will argue that this is not the case, except in the most extreme of circumstances.

Suppose then that, in addition to the traded good discussed so far, there is a nontraded good that also must be produced using capital and labor through a neoclassical production function. Let the two goods together enter as arguments into an instantaneous per capita utility function.

Presence of the nontraded good poses no difficulty for as long as the traded good continues to be produced in the country. For then the price of the traded good and the rental on capital that are given on the world market will serve to determine the wage within the traded-good industry. The wage and rental together will then determine the price of the nontraded good and, together with income, the demand for it. The wage and rental also determine the capital-labor ratio and the labor-output ratio in the nontraded good industry. Therefore, as long as there is enough labor in the country to satisfy demand at this labor-output ratio and still have something left over for production of the traded good, the traded and nontraded goods can be aggregated and treated collectively very much like the one-sector economy earlier in the paper. ${ }^{25}$

However, in anything but Case I above, per capita income grows without bound and the demand for the nontraded good, if it is a normal good, will grow without bound as well. $^{26}$ Eventually, then, it will surpass what can be produced with the available labor,

${ }^{25}$ Note that only labor provides a constraint on producing the nontraded good, since capital can be obtained from abroad.

${ }^{26}$ Strictly speaking, a positive but declining income elasticity of demand is consistent with a demand that grows indefinitely but nonetheless approaches a finite upper limit. I will ignore this possibility, as well as the possibility of a zero or negative income 
and production of the traded good will cease. From then on, if the country continues to grow, all consumption of the traded good will be obtained from abroad in exchange for the earnings on capital, which have been invested abroad and which have permitted income to increase in the first place. At the same time, production of the nontraded good will employ increasing amounts of capital per worker, increasing the wage but also the price of the nontraded good relative to the traded good. From this point on, the growing economy is once again a one-sector economy in terms of production, but it consumes an additional good that it only imports.

Such an economy will not in general settle into anything like a steady state, since the price of the nontraded good will be continually increasing and consumers will be continually substituting away from it in favor of the traded good. If a steady state were possible, it would require that this rate of substitution be somehow constant over time, and this would surely require an overly restrictive assumption about both the utility function and the production function for the nontraded good.

Rather than attempt to solve such a model explicitly, therefore, I will merely ask whether the presence of the nontraded good will make unbounded growth, such as was found earlier in the paper, impossible. It might seem at first that it would. After all, if traded and nontraded goods were perfect substitutes, then the presence of the nontraded good could not pose a problem, since the two could again be aggregated and the model would behave as before. So in the opposite extreme it might appear that if they were perfect complements instead, then, because it would be impossible to substitute away from the nontraded good at all, the limits on producing it would eventually become limits on growth itself.

This is not the case, however. Even if substitution were impossible in both consumption and production, it would still be possible to increase production of the elasticity, since in any case they would make my main results easier, not harder, to obtain. 
nontraded good in proportion to the growth of population. Thus it is never necessary to reduce per capita consumption of the nontraded good. Then if any substitution in consumption is possible at all-that is, as long as utility continues to increase in consumption of the traded good for any given level of consumption of the nontraded goodthen per capita utility will be able to rise indefinitely.

Only in the very extreme case of absolutely no substitution in consumption (thus L-shaped indifference curves) will the presence of nontraded goods choke off per capita growth completely. In that case-since utility is then constrained by the per capita availability of the nontraded good and since that availability is in turn limited by diminishing returns and the need to invest to keep up with population growth, just as in the closed economy growth model-then the presence of a nontraded good would undermine the main result of this paper. Such a country would be unable to sustain per capita growth just by investing its savings abroad, for the return on that saving would only buy it the traded good and it eventually reaches the point where additional consumption of the traded good does not add to utility.

However, in what is surely the more normal case, some substitution between traded and nontraded goods is possible. In that case, a country with a low population growth rate can once again increase its per capita utility without bound by investing its savings on the world market. As its income rises, its consumption will include an increasing proportion of traded goods, as well as either an increasing or a decreasing per capita quantity of the nontraded good depending on how much substitution is possible. In either case, the wage of labor, the price of the nontraded good, and the utility of the individual consumer, will all rise without bound as growth proceeds. ${ }^{27}$

${ }^{27}$ Unlike earlier in the paper, I have discussed growth here in terms of utility, rather than income or consumption. This is necessary since there are now two goods, the price of which are changing. 


\section{Implications for Two-Class Growth Models}

I already noted the fact that my model is formally identical to a two-class growth model of a closed economy. Thus by simply replacing the word "country" with "class" throughout the preceding sections, one can reinterpret the results as properties of a twoclass model.

The most important, and also the simplest, implication of applying this model to a two-class economy is its interpretation of the meaning of classes. When Pasinetti (1962, p. 272) introduced the two-class model, he defined the capitalist class as "a category of individuals who - owing to the position they occupy in the production process - derive all their incomes ... exclusively from profits ..." The model here shows, however, that the special role that capitalists play in growth depends, not on their earning no labor income at all, but on their share of total labor income being negligible. This can be the case even if capitalists as individuals do provide labor, so long as the number of capitalists remains small compared to the total labor force, due to their lower than average rate of population growth or reproduction. Thus Samuelson and Modigliani's (1966, p. 297) “... difficulty of identifying a class whose sole source of income is income from capital . .." may not be so difficult after all. One needs merely to identify classes that differ in the rates at which their populations grow.

There is, of course, a more serious difficulty with the concept of ongoing classes. This was also noted by Samuelson and Modigliani, and my approach does nothing to alleviate it. The classes, however they are defined, must maintain their identities and their ownership of capital from generation to generation. Thus the model breaks down if capital is transferred from one class to another when individuals or their descendants change classes. This objection to the two-class model applies as well to my two-country 
version, though it is surely less serious in the two-country case, to the extent that international migration is limited. ${ }^{28}$

Finally, my model of a two-class economy also yields an interesting and disturbing implication for the distribution of income between classes. From Proposition 1 it follows that, if the capitalists' propensity to save is large enough, then the capitalists will enjoy an ever increasing per capita income, while the per capita income of workers remains constant. Thus per capita income inequality between classes grows indefinitely. ${ }^{29}$ Applied, again, in the international context, the implication of everincreasing international income inequality is equally disturbing.

${ }^{28}$ On the other hand, even a large amount of labor migration would be consistent with my model if the migrants typically take no capital with them.

${ }^{29}$ This result may be compared to those of Stiglitz (1969) who examined a variety of sources both of equality and of inequality, in the distribution of income and wealth. While Stiglitz did consider, separately, differences in both reproduction and savings rates between classes, he never put the two assumptions together as I do here. 


\section{Appendix}

Note from (36) and the curvature of $f$ that

(A1)

$$
\frac{\mathrm{dk}_{\mathrm{i}}^{*}}{\mathrm{dn}_{1}}<0, \frac{\mathrm{dk}_{1}^{*}}{\mathrm{ds}_{\mathrm{i}}}>0
$$

Suppose for purpose of contradiction that for any $i>1$ there exists $k^{0}$ and $t^{0}$ such that

(A2) $\quad k(t) \leq k^{0}<k_{i}^{*} \quad$ for all $t>t^{0}$

Then

$$
f^{\prime}(k(t)) \geq f^{\prime}\left(k^{0}\right)>f^{\prime}\left(k_{i}^{*}\right)=\frac{n_{1}}{s_{i}}
$$

and

$$
\frac{1}{\rho_{i}} \frac{d \rho_{i}}{d t}=s_{i} f^{\prime}(k)-n_{1} \geq s_{i} f^{\prime \prime}\left(k^{0}\right)-n_{1}>s_{i} f^{\prime}\left(k_{i}^{*}\right)=0
$$

It follows that $\rho_{\mathrm{i}}$ would grow without bound after time $\mathrm{t}^{0}$, eventually surpassing $\mathrm{k}$ itself. This is impossible, since $\mathrm{k}=\sum \rho_{\mathrm{i}}$ and all $\rho_{\mathrm{i}} \geq 0$. Thus by contradiction it follows that

$$
\text { (A5) } \quad \lim _{t \rightarrow \infty} k \geq k_{i}^{*}
$$

and therefore

$$
\lim _{t \rightarrow \infty} k \geq \max _{i>1} k_{i}^{*}
$$


Let î be the country, other than country 1 , with the highest savings propensity.

Thus

(A7) $\quad s_{\hat{i}}=\max _{i>1} s_{i}$

and

(A8) $\quad \hat{k}=f^{-1}\left(\frac{n_{1}}{\hat{s}}\right)=k_{\hat{1}}^{*}$

Then

(A9) $\quad \lim _{t \rightarrow \infty} k \geq \hat{k}$

Thus for all $\mathrm{i}$ such that $1<\mathrm{i} \neq \hat{\mathrm{i}}$, for which therefore $\mathrm{s}_{\mathrm{i}}<\hat{\mathrm{s}}$, it follows that

(A10) $\quad \lim _{\mathrm{t} \rightarrow \infty} \frac{1}{\rho_{\mathrm{i}}} \frac{\mathrm{d} \rho_{\mathrm{i}}}{\mathrm{dt}}=\mathrm{s}_{\mathrm{i}} \mathrm{f}^{\prime}(\mathrm{k})-\mathrm{n}_{1}<0$

and hence

(A11) $\quad \lim _{\mathbf{t} \rightarrow \infty} \rho_{\mathrm{i}}=\mathbf{0}$ 
References

Bardhan, P. K. (1965) "Equilibrium Growth in the International Economy," Quarterly Journal of Economics, 74 (August), pp. 455-64.

(1966) "On Factor Accumulation and the Pattern of International Specialization," Review of Economic Studies 33 (January), pp. 39-44.

Buiter, Willem H. (1981) "Time Preference and International Lending and Borrowing in an Overlapping-Generations Model," Journal of Political Economy, 89 (August) pp. 769-97.

Deardorff, Alan V. (1974) "A Geometry of Growth and Trade," Canadian Journal of Economics 7 (May), pp. 295-306.

Deardorff, Alan V. (1987) "Trade and Capital Mobility in a World of Diverging Populations," in D. Gale Johnson and Ronald D. Lee, eds., Population Growth and Economic Development: Issues and Evidence, University of Wisconsin Press, Madison, WI, pp. 561-588.

Findlay, Ronald (1984) "Growth and Development in Trade Models," in Ronald W. Jones and Peter B. Kenen, eds., Handbook of International Economics, Volume I, North-Holland, Amsterdam, Chapter 4.

Grossman, Gene M. and Elhanan Helpman (1989a) "Comparative Advantage and LongRun Growth," Working Paper No. 2809, National Bureau of Economic Research.

Grossman, Gene M. and Elhanan Helpman (1989b) "Growth and Welfare in a Small Open Economy," Discussion Paper in Economics No. 2913, Woodrow Wilson School of Public and International Affairs, Princeton University.

Grossman, Gene M. and Elhanan Helpman (1989c) "Quality Ladders and Product Cycles," Working Paper No. 3201, National Bureau of Economic Research.

Guha, Ashok (1972) "The Global Stability of Two-Class Neoclassical Growth," Quarterly Journal of Economics 86 (November), pp. 687-90.

Helpman, Elhanan (1988) "Growth, Technological Progress, and Trade," Empirica Austrian Economic Papers 1, pp. 5-25.

Johnson, Harry G. (1971) "Trade and Growth: A Geometrical Exposition," Journal of International Economics 1 (February), pp. 83-101.

Kemp, Murray C. (1969) The Pure Theory of International Trade and Investment, Prentice-Hall, Englewood Cliffs, New Jersey.

Khang, C. and M.C. Kemp (1973) "International Trade and Investment between Countries with Different Natural Rates of Growth," Metroeconomica 25, pp. 215228.

Kurz, M. (1968) "The General Instability of a Class of Competitive Growth Processes," Review of Economic Studies 35 (April), pp. 155-174. 
Lucas, Robert E. Jr. (1988) "On the Mechanics of Economic Development," Journal of Monetary Economics 22, pp. 3-42.

Oniki, H. and Uzawa, H. (1965) "Patterns of Trade and Investment in a Dynamic Model of International Trade," Review of Economic Studies 32 (January), pp. 15-38.

Pasinetti, L. (1962) "The Rate of Profit and Income Distribution in Relation to the Rate of Economic Growth," Review of Economic Studies (October).

Romer, Paul M. (1986) "Increasing Returns and Long-Run Growth," Journal of Political Economy 94, pp. 1002-1037.

Samuelson, Paul A. and Modigliani, Franco (1966) "The Pasinetti Paradox in Neoclassical and More General Models," Review of Economic Studies (October), pp. 269-302.

Smith, Alasdair (1984) "Capital Theory and Trade Theory," in Ronald W. Jones and Peter B. Kenen, eds., Handbook of International Economics, Volume I, NorthHolland, Amsterdam, Chapter 6.

Solow, Robert M. (1956) “A Contribution to the Theory of Economic Growth," Quarterly Journal of Economics 70 (February), pp. 65-94.

Stiglitz, J. E. (1967) "A Two-Sector Two Class Model of Economic Growth," Review of Economic Studies 34 (April), pp. 227-38.

(1969) "Distribution of Income and Wealth Among Individuals," Econometrica 37 (July), pp. 382-97.

Swan, T. W. (1956) "Economic Growth and Capital Accumulation," Economic Record 32 , pp. 334-361.

Vanek, Jaroslav (1971) "Economic Growth and International Trade in Pure Theory," Quarterly Journal of Economics 85 (August), pp. 377-90.

Uzawa, Hirofumi (1968) "Time Preference, the Consumption Function, and Optimum Asset Holdings," in J. N. Wolfe, ed., Papers in Honour of Sir John Hicks: Value, Capital, and Growth, Edinburgh University Press, Edinburgh. 
\#50

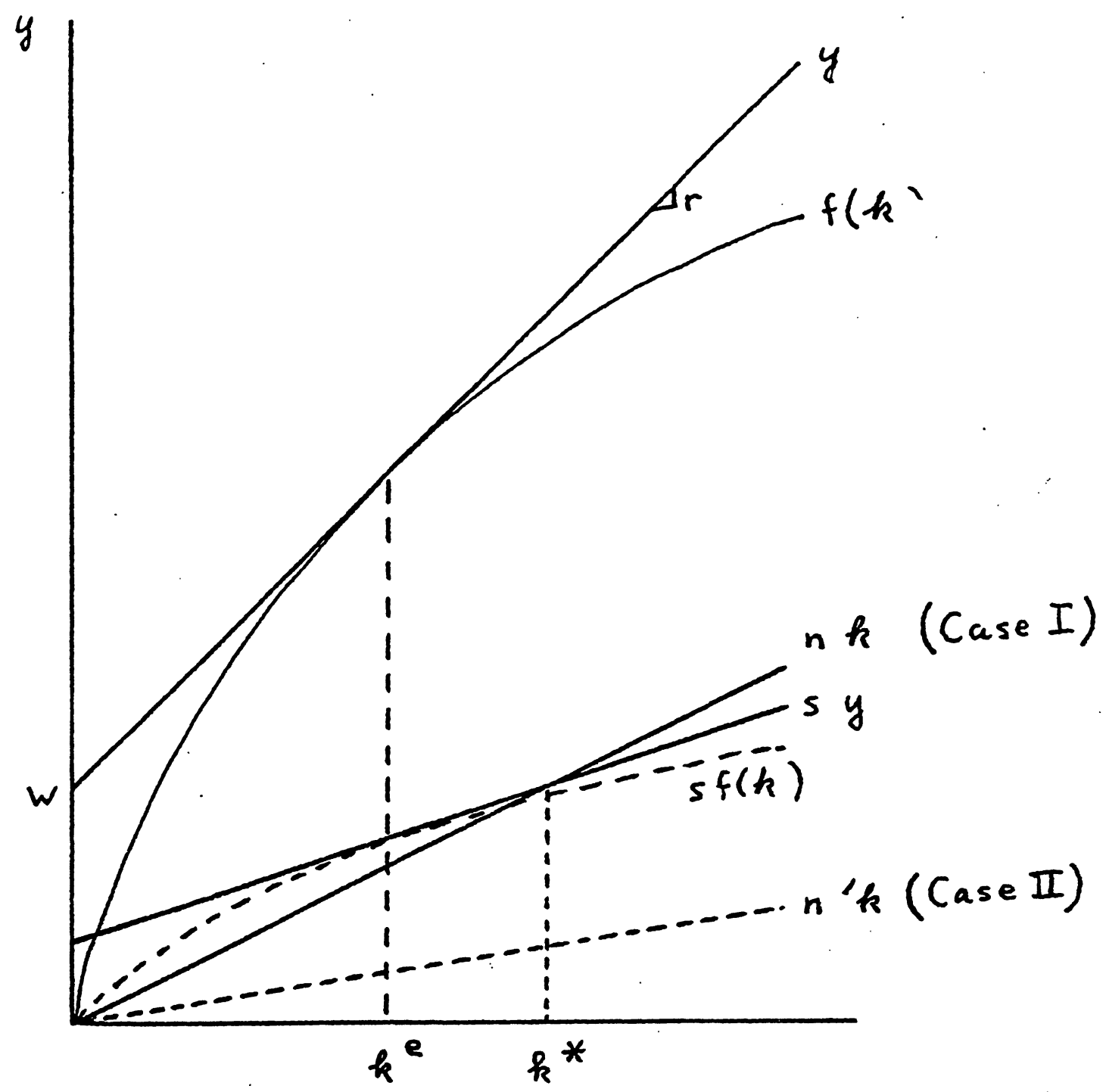

Figure 1 


$$
\tau \operatorname{arn} b ! y
$$

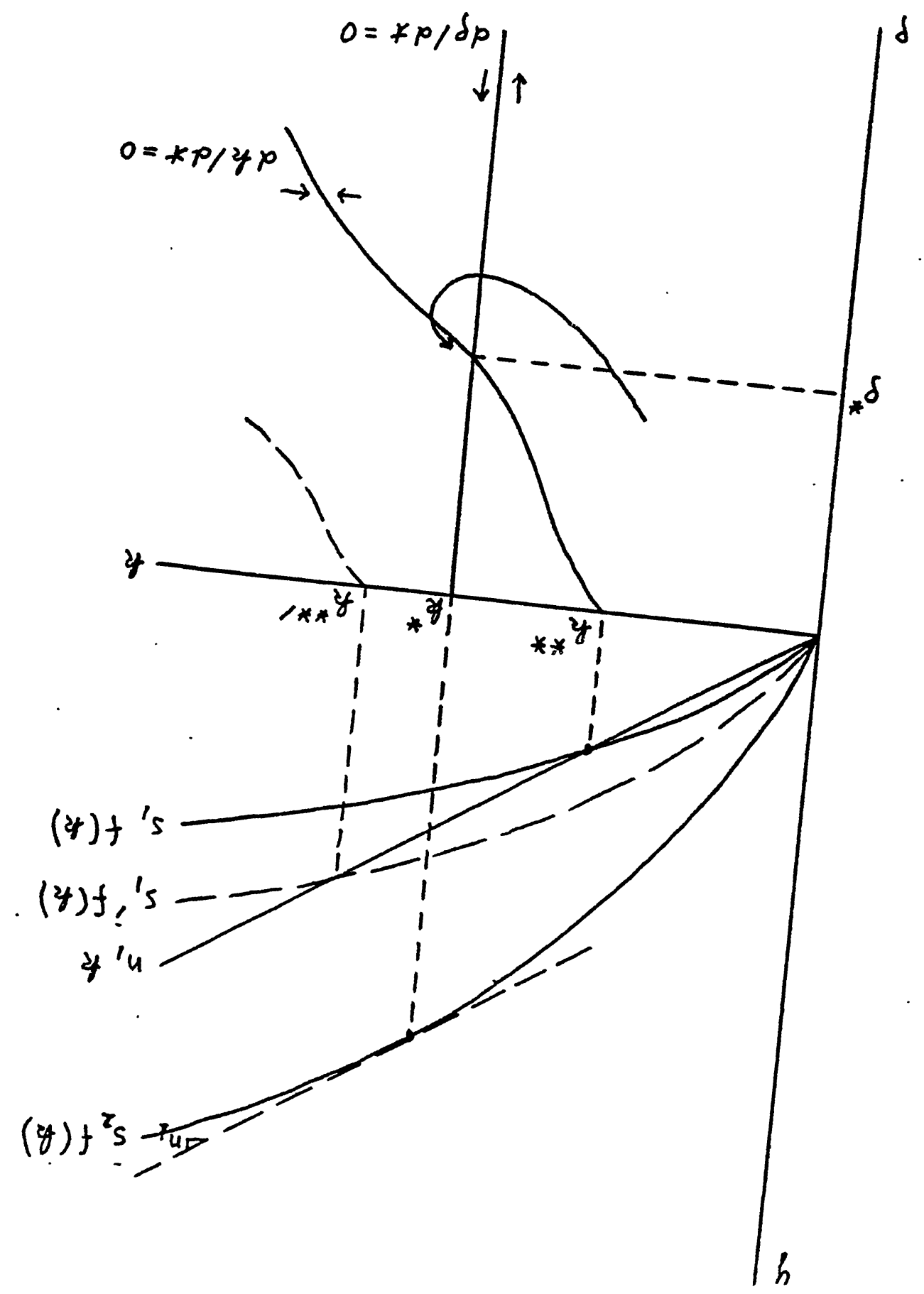

